Review Article

\title{
Role of Shear Stress on Renal Proximal Tubular Cells for Nephrotoxicity Assays
}

\author{
Holly H. Birdsall $\mathbb{I D}^{1,2,3,4}$ and Timothy G. Hammond $\mathbb{D}^{3,4,5,6}$ \\ ${ }^{1}$ Departments of Otorhinolaryngology, Immunology, and Psychiatry, Baylor College of Medicine, Houston, TX 77030, USA \\ ${ }^{2}$ Otolaryngology Section, Surgery Service Line, Durham VA Health Care System, 508 Fulton Street, Durham, NC 27705, USA \\ ${ }^{3}$ Nephrology Section, Department of Medicine, Tulane University School of Medicine, 1430 Tulane Ave, New Orleans 70112, USA \\ ${ }^{4}$ Space Policy Institute, Elliott School of International Affairs, George Washington University, Washington, DC 20052, USA \\ ${ }^{5}$ Nephrology Section, Medicine Service Line, Durham VA Health Care System, 508 Fulton Street, Durham, NC 27705, USA \\ ${ }^{6}$ Nephrology Division, Department of Internal Medicine, Duke University School of Medicine, Durham, NC 27705, USA
}

Correspondence should be addressed to Timothy G. Hammond; hammondoutofoffice@yahoo.com

Received 27 December 2020; Accepted 24 March 2021; Published 22 April 2021

Academic Editor: Anthony DeCaprio

Copyright (C) 2021 Holly H. Birdsall and Timothy G. Hammond. This is an open access article distributed under the Creative Commons Attribution License, which permits unrestricted use, distribution, and reproduction in any medium, provided the original work is properly cited.

\begin{abstract}
Drug-induced nephrotoxicity causes huge morbidity and mortality at massive financial cost. The greatest burden of drug-induced acute kidney injury falls on the proximal tubular cells. To maintain their structure and function, renal proximal tubular cells need the shear stress from tubular fluid flow. Diverse techniques to reintroduce shear stress have been studied in a variety of proximal tubular like cell culture models. These studies often have limited replicates because of the huge cost of equipment and do not report all relevant parameters to allow reproduction and comparison of studies between labs. This review codifies the techniques used to reintroduce shear stress, the cell lines utilized, and the biological outcomes reported. Further, we propose a set of interventions to enhance future cell biology understanding of nephrotoxicity using cell culture models.
\end{abstract}

The inability to accurately identify nephrotoxicity is a major issue for drug development. Nephrotoxicity is the commonest reason to prolong hospital stays in the United States and elsewhere [1]. Acute kidney injury commonly progresses to end-stage renal disease and the need for renal replacement therapy, e.g., dialysis or transplantation, with its substantial costs and morbidity [2-4]. Fourteen drugs were withdrawn from the market between 1990 and 2010 for nephrotoxicity that had not been detected with available screening strategies [5].

There is currently no FDA-approved in vitro test for nephrotoxicity [6]. A major contributing factor is the lack of a readily available cellular target that is an accurate, representative, and physiologically relevant model of cells in the living kidney. Proximal tubule cells (PTC) are a prime candidate for an in vitro assay of nephrotoxicity. PTC are primarily responsible for the uptake and metabolism of drugs in the kidney [7-9] and are a target for damage from many commonly prescribed clinical drugs including aminoglycoside antibiotics, amphotericin B, radiocontrast media, immunoglobulins, and diverse antineoplastic agents $[7,8]$.

PTC rapidly dedifferentiates under traditional 2D culture conditions, e.g., 96-well tissue culture plates, which severely limits the utility of this format for in vitro toxicity assays [10]. What PTC need is exposure to fluid shear stress. In vivo, PTC are exposed to fluid shear stress as the blood filtrate from the glomerulus flows past them en route to becoming urine. They sense this shear stress and respond with structural and biochemical changes, changes that need to be maintained in the in vitro environment.

Fukuda et al. found that human primary PTC exposed to fluid shear stress for 24 hours increased their expression of several drug transporters, including SLC37A2, SLS33A2, and SLC47A1 (also known at MATE2-K [11]. Xu et al. found that primary rat tubules maintained their express of $\mathrm{P} 450$ 
CYP1A1 for 12 days if exposed to shear fluid stress in a gyrorotatory culture [12]. Mollet et al. found that HK-2 cells exposed to fluid shear stress in a bioreactor, compared to static cultures, maintained their expression of multiple membrane transporter proteins for 21 days, including PEPT1 (SLC15A1), PEPT 2 (SLC15A2), OCT1 (SLC22A1), OAT3 (SLC22A8), gamma glutamyl transferase (gGT), and sodium-glucose cotransporter-2 (SGLT2) [13]. Unfortunately, none of these authors reported the intensity of the fluid shear stress that was applied to the PTC.

The magnitude of the shear stress to which PTC are exposed is dependent on the quantity of filtrate flowing past, the viscosity of the filtrate, and the internal structure of the proximal tubule. The proximal tubule narrows as one moves distally, the length and density of their microvilli changes, and the composition of the fluid changes as the PTC reabsorb water, proteins, and other components. However, the flow in the initial portion of the proximal tubule can be estimated from the single-nephron glomerular filtration rate of 30 and $90 \mathrm{~nL} / \mathrm{min}$ [14]. This would suggest that PTC in vivo are exposed to approximately $0.05-0.17$ dynes $/ \mathrm{cm}^{2}$ of shear stress [15] which is much lower than the 5 to 100 dynes $/ \mathrm{cm}^{2}$ that endothelial cells encounter in the vascular system [16]. These low levels of shear stress are challenging to reproduce in vitro in a uniform manner, particularly when they must be implemented in high throughput applications.

In vitro studies with PTC have used a wide range of shear stresses applied for varying durations, making it impossible to compare results between laboratories. What is needed is a standard uniform method of applying shear stress in vitro that is simple and easy to implement. Two issues have limited studies on shear stress. First, the equipment is usually high-priced, which creates significant capitol barriers to experimentation [17-19]. Second, few techniques to reintroduce shear have thoroughly defined the parameters for reproduction by other labs [20].

This review seeks to categorize the known literature on reintroduction of shear stress on renal proximal tubule cell and the utility of suspension culture models which reintroduce shear to model renal damage. The current aim is to understand the amount of shear induced by different cell culture methods, the cell types utilized, and the outcomes assayed. These insights allow us to recommend interventions in the field of drug-induced nephrotoxicity to move the field forward. We performed PubMed searches using the terms renal proximal tubular cells, suspension culture, bioreactor, proximal tubule, renal cell shear stress, nephrotoxicity, drug toxicity, acute tubular necrosis, and renal genomics. We identified 25 papers that used PTC (or PTC cell lines) and specified the intensity of the shear stress flow and the duration of the stimulus.

Figure 1 compares the intensity and duration of shear stress applied to PTC in these 25 publications. The marker shape indicates the method utilized to generate the shear stress, most of which are microfluidics and parallel plate studies. Each study is referenced with a number, defined in Table 1. This graph gives a stark account of why the field has not come to a universal model for studies of nephrotoxicity:

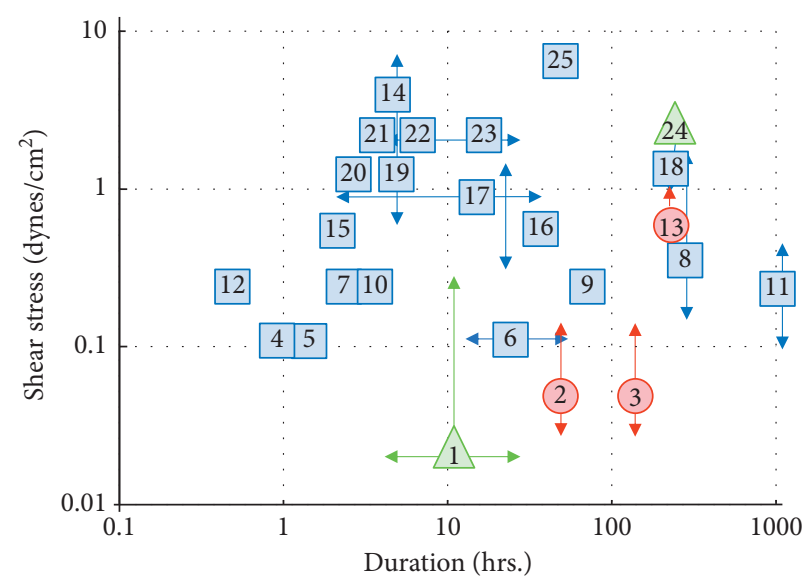

FIGURE 1: Varying conditions used to expose PTC to shear stress in vitro. The graph illustrates the varying intensity and duration of shear stress applied to cultured PTC from 25 reports in the literature. The $y$-axis is the intensity of shear force in dynes $/ \mathrm{cm}^{2}$, and the $x$-axis is the duration of the exposure in hours. When a report used multiple of conditions, arrows indicate the range of intensities, and/or times and the marker is placed at the average value. Each publication is indicated with a number which corresponds to the citation in Table 1. The marker shape indicates the method used to apply the fluid shear stress: blue squares are parallel plates and microfluidics, red circles are rotating wall suspension culture, and green triangles are stirring bioreactors and orbital shakers.

the miscellany of cell types, shear levels applied, and duration of exposure defies simple interpretation.

Fluid shear stress induces structural changes in PTC (Table 1). Reorganization of actin fibers and the cytoskeleton was frequently observed, particularly in experiments using higher intensities of fluid shear stress. The studies that applied higher intensities of shear stress are useful as elevated levels of shear stress on PTC have been implicated in the progression of renal disease [41-45]. Increased expression of microvilli in the presence of fluid shear stress was also noted by multiple authors (Table 1). This is critical, as the microvilli are the sensors for tubular flow and shear stress $[23,29,31,46,47]$.

Of critical importance to the development of an in vitro nephrotoxicity assay, fluid shear stress also increases the quantity and/or activity of transporters that take up proteins and drugs (Table 1). Exposure to fluid shear stress causes PTC to express more megalin and cubilin, transporters that are central part of the proximal tubular uptake of albumin, many other proteins, and drugs [48-50]. Indeed, albumin transport increases when PTC are exposed to fluid shear stress (Table 1). Renal cells employ a variety of organic anion transporters (OATs) and organic cation transporters (OCTs) [51] in the uptake and secretion of drugs. Fluid shear stress has also been observed to upregulate many of these on PTC including MATE (SLC47A1), OCT2 (SLC22A2), P-gp (ABCB1 or MDR1), MAT2K (SLC472K), and MRP2/4 (ABCC2/4). Jang et al. noted that the P-gp efflux by human primary PTC exposed to 0.2 dynes $/ \mathrm{cm}^{2}$ shear stress in vitro was closer to that observed in vivo compared to PTC in static 2D cultures [27]. 
TABLE 1: The study reference, shear stress in dynes $/ \mathrm{cm}^{2}$, duration in hours, technology utilized, and cell type.

\begin{tabular}{|c|c|c|c|c|c|c|c|c|}
\hline \multirow[b]{2}{*}{$\begin{array}{l}\text { Reference } \\
\text { number }\end{array}$} & \multirow[b]{2}{*}{$\begin{array}{l}\text { Shear } \\
\text { stress } \\
(\text { dynes/ } \\
\left.\mathrm{cm}^{2}\right)\end{array}$} & \multirow[b]{2}{*}{$\begin{array}{c}\text { Duration } \\
\text { (hours) }\end{array}$} & \multirow[b]{2}{*}{$\begin{array}{c}\text { Fluid shear } \\
\text { stress } \\
\text { generated with }\end{array}$} & \multirow[b]{2}{*}{ Cell } & \multicolumn{4}{|c|}{ Response of PTC to fluid shear stress } \\
\hline & & & & & $\begin{array}{l}\text { Reorganized } \\
\text { actin and } \\
\text { cytoskeleton }\end{array}$ & $\begin{array}{l}\text { Increased } \\
\text { microvilli }\end{array}$ & $\begin{array}{l}\text { Increased } \\
\text { cubilin/ } \\
\text { megalin, } \\
\text { albumin } \\
\text { transport }\end{array}$ & $\begin{array}{c}\text { Increased } \\
\text { expression of } \\
\text { drug } \\
\text { transporters }\end{array}$ \\
\hline $\begin{array}{l}\text { 1. Bhat } 1995 \\
{[21]}\end{array}$ & $0.02-0.27$ & $12-15$ & $\begin{array}{l}\text { Spinner flasks } \\
\text { with stirrers }\end{array}$ & MDCK (canine) & $\mathbf{X}$ & & & \\
\hline $\begin{array}{l}\text { 2. Cowger } 2000 \\
{[22]}\end{array}$ & $0.04-0.12$ & 48 & $\begin{array}{l}\text { Rotating wall } \\
\text { vessel } \\
\text { suspension }\end{array}$ & $\begin{array}{l}\text { Primary PTC } \\
\text { (human) }\end{array}$ & & & & \\
\hline $\begin{array}{l}\text { 3. Hammond } \\
1999 \& 2000 \\
{[20]}\end{array}$ & $0.04-0.12$ & 144 & $\begin{array}{l}\text { Rotating wall } \\
\text { vessel } \\
\text { suspension }\end{array}$ & $\begin{array}{c}\text { Primary PTC } \\
\text { (human and rat) }\end{array}$ & & & & \\
\hline $\begin{array}{l}\text { 4. Raghavan } \\
2014[23]\end{array}$ & $0.1^{*}$ & $0.25-0.5$ & MIcrofluidics & $\begin{array}{l}\text { LLC-PK1 (pig), } \\
\text { OK (possum) }\end{array}$ & & & $\mathbf{X}$ & \\
\hline $\begin{array}{l}\text { 5. Miravete } 2011 \\
{[24]}\end{array}$ & $0.5-5$ & 1 & Parallel plate & HK-2 (human) & & & & \\
\hline $\begin{array}{l}\text { 6. Shimony } \\
2008[25]\end{array}$ & 0.1 & $24-48$ & Slow rotation) & $\begin{array}{c}\text { MDCK } \\
\text { (canine), HK-2 } \\
\text { (human) }\end{array}$ & & & & \\
\hline 7. Xu 2020 [12] & 0.2 & 2.5 & Microfluidics & HK-2 (human) & & & $\mathbf{X}$ & \\
\hline $\begin{array}{l}\text { 8. Jayagopal } \\
2019 \text { [26] }\end{array}$ & $0.2-2$ & 240 & Parallel plate & MDCK (canine) & & & & $\begin{array}{l}\text { MATE \& } \\
\text { OCT2 }\end{array}$ \\
\hline $\begin{array}{l}\text { 9. Jang } 2013 \\
\text { [27] }\end{array}$ & 0.2 & 72 & Microfluidics & $\begin{array}{c}\text { Primary PTC } \\
\text { (human) }\end{array}$ & & $\mathbf{X}$ & $\mathbf{X}$ & P-gp \\
\hline $\begin{array}{l}\text { 10. Duan } 2010 \\
\text { [28] }\end{array}$ & 0.2 & 3 & Parallel plate & $\begin{array}{l}\text { Primary PTC } \\
\text { (murine) }\end{array}$ & $\mathbf{X}$ & & & \\
\hline $\begin{array}{l}\text { 11. Homan } 2016 \\
\text { [29] }\end{array}$ & $0.1-0.5$ & 1008 & $\begin{array}{l}\text { Perfused 3-D } \\
\text { construct }\end{array}$ & PTC-hTERT1 & $\mathbf{X}$ & $\mathbf{X}$ & $\mathbf{X}$ & \\
\hline $\begin{array}{l}\text { 12. Carrisoza- } \\
\text { gaytan } 2014 \\
{[30]}\end{array}$ & 0.2 & 0.5 & Parallel plate & $\begin{array}{r}\text { mpkCCD } \\
\text { (murine) }\end{array}$ & $\mathbf{X}$ & & & \\
\hline $\begin{array}{l}\text { 13. Kaysen } 1999 \\
\text { [31] }\end{array}$ & $0.5-1$ & $240-384$ & $\begin{array}{l}\text { Rotating wall } \\
\text { vessel } \\
\text { suspension }\end{array}$ & $\begin{array}{l}\text { Primary PTC } \\
\text { (rat and human) }\end{array}$ & & $\mathbf{X}$ & $\mathbf{X}$ & \\
\hline $\begin{array}{l}\text { 14. Brakeman } \\
2016[32]\end{array}$ & $0.5-5$ & 5 & Microfluidics & $\begin{array}{c}\text { Primary PTC } \\
\text { (human) }\end{array}$ & & & & \\
\hline $\begin{array}{l}\text { 15. Frohlich } \\
2012[33]\end{array}$ & 0.5 & 2 & Parallel plate & HK-2 (human) & $\mathbf{X}$ & & & \\
\hline $\begin{array}{l}\text { 16. Fukuda } 2017 \\
\text { [11] }\end{array}$ & 0.5 & $24-48$ & Parallel plate & $\begin{array}{c}\text { Primary PTC } \\
\text { (human) }\end{array}$ & & & & MAT2K \\
\hline $\begin{array}{l}\text { 17. Essig } 2001 \\
{[15]}\end{array}$ & $0.04-0.17$ & $2-24$ & Parallel plate & $\begin{array}{l}\text { Primary PTC } \\
\text { (murine) and } \\
\text { LLC-PK1 }\end{array}$ & $\mathbf{X}$ & & & \\
\hline $\begin{array}{l}\text { 18. Vriend } 2020 \\
\text { [34] }\end{array}$ & $0.5-2.0$ & 216 & Microfluidics & $\begin{array}{l}\text { Immortalized } \\
\text { hu PTC }\end{array}$ & & & $\mathbf{X}$ & $\begin{array}{l}\text { MRP2/4 and } \\
\text { P-gp }\end{array}$ \\
\hline $\begin{array}{l}\text { 19. Duan } 2008 \\
\text { [35] }\end{array}$ & 1.0 & 5 & Parallel plate & $\begin{array}{l}\text { Primary PTC } \\
\text { (murine) }\end{array}$ & $\mathbf{X}$ & & & \\
\hline $\begin{array}{l}\text { 20. Ferrell } 2012 \\
\text { [36] }\end{array}$ & 1.0 & 3 & MIcrofluidics & $\begin{array}{l}\text { Primary PTC } \\
\text { (murine) }\end{array}$ & & & $\mathbf{X}$ & \\
\hline $\begin{array}{l}\text { 21. Kunnen } \\
2017 \text { [37] }\end{array}$ & 1.9 & $4-20$ & $\begin{array}{l}\text { Parallel plate } \\
\text { and cone-plate }\end{array}$ & $\begin{array}{c}\text { SV40 } \\
\text { transformed } \\
\text { PTC (murine) }\end{array}$ & $\mathbf{X}$ & & & \\
\hline $\begin{array}{l}\text { 22. Cattaneo } \\
2011[38]\end{array}$ & 2.0 & 6 & Parallel plate & MDCK (canine) & $\mathbf{X}$ & & & \\
\hline $\begin{array}{l}\text { 23. Kunnen } \\
\text { 2018b [39] }\end{array}$ & 2.0 & $4-16$ & Parallel plate & $\begin{array}{c}\text { SV40 } \\
\text { transformed } \\
\text { PTC (murine) }\end{array}$ & $\mathbf{X}$ & & & \\
\hline
\end{tabular}


TABLE 1: Continued.

\begin{tabular}{|c|c|c|c|c|c|c|c|c|}
\hline \multirow[b]{2}{*}{$\begin{array}{l}\text { Reference } \\
\text { number }\end{array}$} & \multirow[b]{2}{*}{$\begin{array}{l}\text { Shear } \\
\text { stress } \\
(\text { dynes/ } \\
\left.\mathrm{cm}^{2}\right)\end{array}$} & \multirow[b]{2}{*}{$\begin{array}{c}\text { Duration } \\
\text { (hours) }\end{array}$} & \multirow[b]{2}{*}{$\begin{array}{c}\text { Fluid shear } \\
\text { stress } \\
\text { generated with }\end{array}$} & \multirow[b]{2}{*}{ Cell } & \multicolumn{4}{|c|}{ Response of PTC to fluid shear stress } \\
\hline & & & & & $\begin{array}{l}\text { Reorganized } \\
\text { actin and } \\
\text { cytoskeleton }\end{array}$ & $\begin{array}{l}\text { Increased } \\
\text { microvilli }\end{array}$ & $\begin{array}{l}\text { Increased } \\
\text { cubilin/ } \\
\text { megalin, } \\
\text { albumin } \\
\text { transport }\end{array}$ & $\begin{array}{c}\text { Increased } \\
\text { expression of } \\
\text { drug } \\
\text { transporters }\end{array}$ \\
\hline $\begin{array}{l}\text { 24. Ferrell } 2018 \\
\text { [40] }\end{array}$ & 2.0 & $6-240$ & Orbital shaker & $\begin{array}{c}\text { Primary PTC } \\
\text { (human) }\end{array}$ & $\mathbf{X}$ & & & \\
\hline $\begin{array}{l}\text { 25. Maggiorani } \\
2015 \text { [41] }\end{array}$ & 5.0 & 48 & Parallel plate & HK-2 (human) & $\mathbf{X}$ & & & \\
\hline
\end{tabular}

*Initially reported as 1.0 dynes $/ \mathrm{cm}^{2}$; corrected in errata to 0.1 dynes $/ \mathrm{cm}^{2}$. This table displays the effects of fluid shear stress on PTC in vitro. The data are abstracted from 25 publications that reported the amount of shear stress applied (dynes $\left./ \mathrm{cm}^{2}\right)$ and the duration of the stimulus. When a range of intensities or exposure times was used, arrows indicate the range and the symbol is placed at the average amount. The PTC cell types used included primary cells (from human, mouse, or rat), MadinDarby Canine Kidney (MDCK) cell line, Human papilloma-transduced PTC (HK-2), SV40-transformed murine PTC, LLC-PK1 (pig kidney line), and OK (opossum kidney cell line). The reference numbers are the key for Figure 1.

With a specific focus on suspension culture and shear stress effects on renal proximal tubular cells, this review expands and enhances a specific segment of the Good Cell Culture Practice (GCCP) initiative [52] started by the former European Center for the Validation of Alternative Methods (ECVAM) [53]. The GCCP program tries to define standardized protocols to cultivate all relevant human tissues/ organs to test toxicity of newly developed drugs and chemicals.

The diversity of shear stress levels and durations in the studies reviewed here emphasizes the need for systematic reporting of specific criteria in order to produce a knowledge base to support harmonized protocols. Our lab proposed this more than a decade ago, embodied in the Bonn criteria [20]. While there are developments on the way to generate harmonized protocols that should allow for prediction of nephrotoxicity during the preclinical phase of drug development [54-56], each methodology will need the kind of summary review presented here to allow useful progression of the initiatives.

The duration of shear exposure and cell type have striking effects on cellular responses (Table 1). It is a conundrum to compare studies not only because of differing shear stress, duration, and cell types, but the various studies utilized diverse outcome measures. A few studies have examined different shear levels and demonstrated changes dependent on shear levels $[21,29,31]$. There is scant, if any, data on the time course of changes in selected outcomes. Hence, study of changes in outcomes over time is one of our suggestions for future study.

Only with harmonized protocols that define the shear stress applied on renal proximal tubules can many of the questions pivotal to predicting nephrotoxicity be answered: does shear induce certain specific patterns in gene expression? Is there an interdependency between the magnitude of shear stress and the expression of specific genes? How do the effects of cells exposed to shear stress or under microfluidic conditions compare? Can the change in phenotypic function of proximal tubular cells in culture towards an in vivo equivalent state be achieved by shear stress alone?

\section{Conclusions}

We propose three strategies to move the field towards a uniform model to test nephrotoxicity of drugs.

First, in 2010, we proposed a minimum data set to be reported to allow reproduction of suspension culture studies in other labs [20]. As the meeting where the proposal was presented was in Bonn, we termed these the Bonn criteria [20]. They include the vessel diameter, rotation speed, media viscosity, media density, cell/organoid/spheroid diameter, and density. The Bonn criteria remain critical to interpret data between labs and allow accurate experimental reproduction between labs.

Second, if different labs continue to use different techniques and reagents including cell types, some tradeoff or bake-off studies will be indispensable to understand differences between approaches.

Last, the development of a low capital, inexpensive, touse suspension culture technology would allow far more labs access to the technology and occasion the opportunity for studies to include more replicates and conditions costeffectively.

The search for a uniform model to study nephrotoxicity is severely limited by the use of a multiplicity of methods and techniques, which cannot be simply compared. Laboratories use different cell types approximating renal proximal tubular cells and apply diverse shear stress methods, and there is no systematic and adequate reporting of culture parameters. The morbidity, mortality, and cost of drug induced acute renal injury should make an integrated cell biology approach to nephrotoxicity an urgent priority.
Abbreviations
gGT: Gamma glutamyl transferase
MATE: Multidrug and toxin extrusion protein
MDCK: MadinDarby Canine Kidney
Pgp: $\quad$ P glycoprotein transporter
PETP: Peptide transporter
PTC: Proximal tubule cells
OAT: Organic anion transporters
OCT: Organic cation transporters. 


\section{Data Availability}

All articles cited are freely available on PubMed and other academic media.

\section{Disclosure}

The content does not represent the views of the Department of Veterans Affairs or the United States of America.

\section{Conflicts of Interest}

The authors declare that they have no conflicts of interest.

\section{Acknowledgments}

This material is the result of work supported with resources and the use of facilities at the Durham Veterans Affairs Health Care System and Duke University School of Medicine. This study was also supported by the NASA grant to the Institute for Medical Research (80NSSC19K0706).

\section{References}

[1] S. A. Silver, J. Long, Y. Zheng, and G. M. Chertow, "Cost of acute kidney injury in hospitalized patients," Journal of Hospital Medicine, vol. 12, no. 2, pp. 70-76, 2017.

[2] D. P. Basile, M. D. Anderson, and T. A. Sutton, "Pathophysiology of acute kidney injury," Comprehensive Physiology, vol. 2, no. 2, pp. 1303-1353, 2012.

[3] M. A. Perazella, "Drug-induced acute kidney injury," Current Opinion in Critical Care, vol. 25, no. 6, pp. 550-557, 2019.

[4] R. Savin, N. Lameire, L. Annemans, and W. Van Biesen, "Cost of renal replacement: how to help as many as possible while keeping expenses reasonable?" Nephrology Dialysis Transplantation, vol. 31, no. 8, pp. 1251-1261, 2016.

[5] N. S. Hay, B. S. Lopes, L. Tomás, and S. F. Almeida, "Drug withdrawal due to safety: a review of the data supporting withdrawal decision," Current Drug Safety, vol. 15, no. 1, pp. 4-12, 2020.

[6] F. Dieterle, F. Sistare, F. Goodsaid et al., "Renal biomarker qualification submission: a dialog between the FDA-EMEA and predictive safety testing consortium," Nature Biotechnology, vol. 28, no. 5, pp. 455-462, 2010.

[7] D. Crean, P. Bellwon, L. Aschauer et al., "Development of an in vitro renal epithelial disease state model for xenobiotic toxicity testing," Toxicology in Vitro, vol. 30 , no. 1 , pp. 128-137, 2015.

[8] W. Pfaller and G. Gstraunthaler, "Nephrotoxicity testing in vitro--what we know and what we need to know," Environmental Health Perspectives, vol. 106, no. 2, pp. 559-569, 1998.

[9] M. Ma, G. Stadler, P. Jennings et al., "hTERT alone immortalizes epithelial cells of renal proximal tubules without changing their functional characteristics," American Journal of Physiology-Renal Physiology, vol. 295, no. 5, pp. F1365F1375, 2008.

[10] I. M. Bruggeman, J. J. W. M. Mertens, J. H. M. Temmink, M. C. Lans, R. M. E. Vos, and P. J. Van Bladeren, "Use of monolayers of primary rat kidney cortex cells for nephrotoxicity studies," Toxicology in Vitro, vol. 3, no. 4, pp. 261-269, 1989.

[11] Y. Fukuda, M. Kaishima, T. Ohnishi et al., "Fluid shear stress stimulates MATE2-K expression via Nrf2 pathway activation," Biochemical and Biophysical Research Communications, vol. 484, no. 2, pp. 358-364, 2017.

[12] J. Riedl, D. Patton, S. K. Jackson, and W. M. Purcell, "In-vitro maintenance and functionality of primary renal tubules and their application in the study of relative renal toxicity of nephrotoxic drugs," Journal of Pharmacological and Toxicological Methods, vol. 68, no. 2, pp. 269-274, 2013.

[13] B. B. Grès, I. L. J. Bogaerts, G. C. van Almen, and P. Y. W. Dankers, "A bioartificial environment for kidney epithelial cells based on a supramolecular polymer basement membrane mimic and an organotypical culture system," Journal of Tissue Engineering and Regenerative Medicine, vol. 11, no. 6, pp. 1820-1834, 2017.

[14] J. P. Bonvalet and C. de Rouffignac, "Distribution of ferrocyanide along the proximal tubular lumen of the rat kidney: its implications upon hydrodynamics," The Journal of Physiology, vol. 318, no. 1, pp. 85-98, 1981.

[15] M. Essig, F. Terzi, M. Burtin, and G. Friedlander, "Mechanical strains induced by tubular flow affect the phenotype of proximal tubular cells," American Journal of Physiology-Renal Physiology, vol. 281, no. 4, pp. F751-F762, 2001.

[16] P. F. Schmidt, "Flow-mediated endothelial mechanotransduction," Physiological Reviews, vol. 75, no. 3, pp. 519-560, 1995.

[17] T. Hammond, P. Allen, and H. Birdsall, "Is there a spacebased technology solution to problems with preclinical drug toxicity testing?" Pharmaceutical Research, vol. 33, no. 7, pp. 1545-1551, 2016.

[18] S. V. Hammond, P. X. Er, K. T. Lawlor et al., "Kidney microorganoids in suspension culture as a scalable source of human pluripotent stem cell-derived kidney cells," Development, vol. 146, no. 5, Article ID dev172361, 2019.

[19] A. Przepiorski, V. Sander, T. Tran et al., "A simple bioreactorbased method to generate kidney organoids from pluripotent stem cells," Stem Cell Reports, vol. 11, no. 2, pp. 470-484, 2018.

[20] T. Hammond and P. Allen, "The Bonn criteria: minimal experimental parameter reporting for clinostat and random positioning machine experiments with cells and tissues," Microgravity Science and Technology, vol. 23, no. 2, pp. 271275, 2011

[21] V. D. Bhat, P. A. Windridge, R. S. Cherry, and L. J. Mandel, "Fluctuating shear stress effects on stress fiber architecture and energy metabolism of cultured renal cells," Biotechnology Progress, vol. 11, no. 5, pp. 596-600, 1995.

[22] N. L. Cowger, E. Benes, P. L. Allen, and T. G. Hammond, "Expression of renal cell protein markers is dependent on initial mechanical culture conditions," Journal of Applied Physiology, vol. 92, no. 2, pp. 691-700, 2002.

[23] V. Wolvetang, Y. Rbaibi, N. M. Pastor-Soler, M. D. Carattino, and O. A. Weisz, "Shear stress-dependent regulation of apical endocytosis in renal proximal tubule cells mediated by primary cilia," Proceedings of the National Academy of Sciences, vol. 111, no. 23, pp. 8506-8511, 2014.

[24] M. Miravéte, J. Klein, A. Besse-Patin et al., "Renal tubular fluid shear stress promotes endothelial cell activation," Biochemical and Biophysical Research Communications, vol. 407, no. 4, pp. 813-817, 2011.

[25] N. Shimony, I. Avrahami, R. Gorodetsky et al., "A 3D rotary renal and mesenchymal stem cell culture model unveils cell death mechanisms induced by matrix deficiency and low shear stress," Nephrology Dialysis Transplantation, vol. 23, no. 6, pp. 2071-2080, 2008.

[26] A. Jayagopal, P. R. Brakeman, P. Soler et al., "Apical shear stress enhanced organic cation transport in human OCT2/ 
MATE1-transfected Madin-Darby canine kidney cells involves ciliary sensing," Journal of Pharmacology and Experimental Therapeutics, vol. 369, no. 3, pp. 523-530, 2019.

[27] K.-J. Lewis, A. P. Mehr, G. A. Hamilton et al., "Human kidney proximal tubule-on-a-chip for drug transport and nephrotoxicity assessment," Integrative Biology, vol. 5, no. 9, pp. 1119-1129, 2013.

[28] Y. Duan, A. M. Weinstein, S. Weinbaum, and T. Wang, "Shear stress-induced changes of membrane transporter localization and expression in mouse proximal tubule cells," Proceedings of the National Academy of Sciences, vol. 107, no. 50, pp. 21860-21865, 2010.

[29] K. A. Homan, D. B. Kolesky, M. A. Skylar-Scott et al., "Bioprinting of 3D convoluted renal proximal tubules on perfusable chips," Scientific Reports, vol. 6, no. 1, Article ID 34845, 2016.

[30] R. Carrisoza-Gaytan, Y. Liu, D. Flores et al., "Effects of biomechanical forces on signaling in the cortical collecting duct (CCD)," American Journal of Physiology-Renal Physiology, vol. 307, no. 2, pp. F195-F204, 2014.

[31] J. H. Ingber, W. C. Campbell, R. R Majewski et al., "Select de novo gene and protein expression during renal epithelial cell culture in rotating wall vessels is shear stress dependent," The Journal of Membrane Biology, vol. 168, no. 1, pp. 77-89, 1999.

[32] P. Brakeman, S. Miao, J. Cheng et al., "A modular microfluidic bioreactor with improved throughput for evaluation of polarized renal epithelial cells," Biomicrofluidics, vol. 10, no. 6, Article ID 064106, 2016.

[33] E. M. Frohlich, X. Zhang, and J. L. Charest, "The use of controlled surface topography and flow-induced shear stress to influence renal epithelial cell function," Integrative Biology, vol. 4, no. 1, pp. 75-83, 2012.

[34] J. Vriend, J. G. P. Peters, T. T. G. Nieskens et al., "Flow stimulates drug transport in a human kidney proximal tubuleon-a-chip independent of primary cilia," Biochimica et Biophysica Acta (BBA)-General Subjects, vol. 1864, no. 1, p. 129433, 2020.

[35] Y. Duan, N. Gotoh, Q. Yan et al., "Shear-induced reorganization of renal proximal tubule cell actin cytoskeleton and apical junctional complexes," Proceedings of the National Academy of Sciences, vol. 105, no. 32, pp. 11418-11423, 2008.

[36] N. Ferrell, K. B. Ricci, J. Groszek, J. T. Marmerstein, and W. H. Fissell, "Albumin handling by renal tubular epithelial cells in a microfluidic bioreactor," Biotechnology and Bioengineering, vol. 109, no. 3, pp. 797-803, 2012.

[37] S. J. Kunnen, W. N. Leonhard, C. Semeins et al., "Fluid shear stress-induced TGF- $\beta$ /ALK5 signaling in renal epithelial cells is modulated by MEK1/2," Cellular and Molecular Life Sciences, vol. 74, no. 12, pp. 2283-2298, 2017.

[38] I. Cattaneo, L. Condorelli, A. R. Terrinoni et al., "Shear stress reverses dome formation in confluent renal tubular cells," Cellular Physiology and Biochemistry, vol. 28, no. 4, pp. 673-682, 2011.

[39] S. J. Kunnen, T. B. Malas, C. Formica, W. N. Leonhard, P. A. C. 't Hoen, and D. J. M. Peters, "Comparative transcriptomics of shear stress treated Pkd1-/- cells and precystic kidneys reveals pathways involved in early polycystic kidney disease," Biomedicine \& Pharmacotherapy, vol. 108, pp. 1123-1134, 2018.

[40] N. Ferrell, J. Cheng, S. Miao, S. Roy, and W. H. Fissell, "Orbital shear stress regulates differentiation and barrier function of primary renal tubular epithelial cells," ASAIO Journal, vol. 64, no. 6, pp. 766-772, 2018.
[41] D. Maggiorani, R. Dissard, M. Belloy et al., "Shear stressinduced alteration of epithelial organization in human renal tubular cells," PLoS One, vol. 10, no. 7, Article ID e0131416, 2015.

[42] M. Essig and G. Friedlander, "Shear-stress-responsive signal transduction mechanisms in renal proximal tubule cells," Current Opinion in Nephrology and Hypertension, vol. 12, no. 1, pp. 31-34, 2003.

[43] M. Essig and G. Friedlander, "Tubular shear stress and phenotype of renal proximal tubular cells," Journal of the American Society of Nephrology, vol. 14, no. 1, pp. S33-S35, 2003.

[44] J. Ogasawara-Shimizu, M. Essig, J. Klein et al., "Quand l'urine cisaille les cellules rénales," Médecine/Sciences, vol. 29, no. 3, pp. 279-285, 2013.

[45] T. Srivastava, S. Hariharan, U. S. Alon et al., "Hyperfiltrationmediated injury in the remaining kidney of a transplant donor," Transplantation, vol. 102, no. 10, pp. 1624-1635, 2018.

[46] Z. Baer, Y. Duan, Q. Yan, A. M. Weinstein, S. Weinbaum, and T. Wang, "Mechanosensory function of microvilli of the kidney proximal tubule," Proceedings of the National Academy of Sciences, vol. 101, no. 35, pp. 13068-13073, 2004.

[47] P. Schanstra, A. M. Weinstein, and S. Weinbaum, "A hydrodynamic mechanosensory hypothesis for brush border microvilli," American Journal of Physiology-Renal Physiology, vol. 279, no. 4, pp. F698-F712, 2000.

[48] E. I. Zhang, P. J. Verroust, and R. Nielsen, "Receptor-mediated endocytosis in renal proximal tubule," Pflügers Archiv European Journal of Physiology, vol. 458, no. 6, pp. 1039-1048, 2009.

[49] R. Nielsen, E. I. Christensen, and H. Birn, "Megalin and cubilin in proximal tubule protein reabsorption: from experimental models to human disease," Kidney International, vol. 89, no. 1, pp. 58-67, 2016.

[50] P. J. Verroust, R. Kozyraki, T. G. Hammond, S. K. Moestrup, and E. I. Christensen, "Physiopathologic role of cubilin and megalin," Advances in Nephrology from the Necker Hospital, vol. 30, pp. 127-145, 2000.

[51] S. K. Nigam, W. Wu, K. T. Bush, M. P. Hoenig, R. C. Blantz, and V. Bhatnagar, "Handling of drugs, metabolites, and uremic toxins by kidney proximal tubule drug transporters," Clinical Journal of the American Society of Nephrology, vol. 10, no. 11, pp. 2039-2049, 2015.

[52] A. Bal-Price and S. Coecke, "Guidance on Good cell culture Practice (GCCP)," in Cell Culture Techniques. Neuromethods, S. C. Aschner and A. Bal-Price, Eds., , pp. 1-25, Humana Press, 2011.

[53] S. Coecke, M. Balls, G. Bowe et al., "Guidance on Good cell culture Practice," Alternatives to Laboratory Animals, vol. 33, no. 3, pp. 261-287, 2005.

[54] R. Chen, L. Deng, X. Yu et al., "MiR-122 partly mediates the ochratoxin A-induced GC-2 cell apoptosis," Toxicology in Vitro, vol. 30, no. 1, pp. 264-273, 2015.

[55] W. Combes, D. F. Choy, M. S. Lam, T. Morgan, M. E. Sullivan, and J. M. Post, "Use of cultured cells of kidney origin to assess specific cytotoxic effects of nephrotoxins," Toxicology in Vitro, vol. 17, no. 1, pp. 107-113, 2003.

[56] C. Wang, X. Dai, H. Liu et al., "Involvement of PPAR $\gamma$ in emodin-induced HK-2 cell apoptosis," Toxicology in Vitro, vol. 29, no. 1, pp. 228-233, 2015. 